\title{
Malnutrisi Akut Berat dan Determinannya pada Balita di Wilayah Rural dan Urban
}

\author{
Severe Acute Malnutrition and Determinants among Children in Rural and \\ Urban Communities
}

Titih Huriah*, Laksono Trisnantoro**, Fitri Haryanti***, Madarina Julia****

\begin{abstract}
*Departemen Keperawatan Komunitas Prodi Ilmu Keperawatan FKIK Universitas Muhammadiyah Yogyakarta, **Ilmu Kesehatan Masyarakat FK Universitas Gadjah Mada, ***Prodi Ilmu Keperawatan FK Universitas Gadjah Mada, ****Departemen Ilmu Kedokteran Anak FK Universitas Gadjah Mada
\end{abstract}

\begin{abstract}
Abstrak
Malnutrisi akut berat merupakan malnutrisi yang paling serius yang memengaruhi balita dan merupakan masalah kesehatan utama di negaranegara berkembang. Malnutrisi telah meluas baik di perkotaan maupun perdesaan. Akar permasalahan malnutrisi di negara berkembang salahsatunya adalah faktor sosial demografi. Tujuan penelitian untuk melihat perbedaan kejadian malnutrisi dan determinannya di area perkotaan dan pedesaan di Yogyakarta. Penelitian menggunakan desain potong lintang dengan responden adalah semua balita malnutrisi akut berat di Kabupaten Sleman (23 balita) dan Kota Yogyakarta (33 balita). Analisis data menggunakan statistik deskriptif dan inferensial. Penelitian dilaksanakan pada Bulan Desember 2012 - Februari 2013. Prevalensi balita malnutrisi akut lebih banyak di perkotaan daripada di pedesaan ( $59 \%$ vs. $41 \%$ ). Persentase faktor risiko kejadian malnutrisi pada kelompok urban dan rural adalah jumlah balita dalam keluarga satu orang $(60,7 \%)$, jenis kelamin laki-laki (58,9\%), riwayat pemberian ASI tidak eksklusif $(60,7 \%)$, usia ibu kurang dari 35 tahun $(62,5 \%)$, pekerjaan non-PNS $(98,2 \%)$, penghasilan orang tua lebih dari UMR (58,9\%), tingkat pendidikan ayah dan ibu tinggi (71,4\% dan $64,3 \%)$ dan pengasuh balita di rumah adalah ibu $(82,1 \%)$. Perbedaan yang signifikan $(p<0,05)$ pada variabel pekerjaan dan penghasilan orang tua, tingkat pendidikan orang tua dan pengasuh balita, sedangkan hasil pengukuran antropometri tidak menunjukkan adanya perbedaan. Determinan kejadian malnutrisi pada kelompok urban dan rural adalah jumlah balita dalam keluarga.
\end{abstract}

Kata kunci: Balita, karakteristik demografi, malnutrisi akut berat, rural, urban

\section{Abstract}

Severe acute malnutrition is the most serious form of malnutrition affecting children under-five and widely recognized as a major health problem in developing countries. It is wide spread in rural and urban areas. Social demographic factor is one of the main causes of severe acute malnutrition.
This study was conducted to determine the prevalence of severe acute malnutrition and determinants of children in urban and rural area in Yogyakarta. A cross-sectional study was used in this study, where the respondents were all children with severe acute malnutrition in Sleman and Yogyakarta (23 and 33 children respectively). Descriptive and inferencial statistic were used to analyze the data. The study was carried out in December 2012-February 2013. The prevalence of severe acute malnutrition children was higher in urban than rural communities ( $59 \%$ vs. $41 \%$ ). Risk factors percentage of malnourished were number of children in family was one person $(60.7 \%)$, male gender $(58.9 \%)$, the history of not exclusive breastfeeding $(60.7 \%)$, mother age less than 35 years old (62.5\%), lower class job (98.2\%), monthly income was high $(58.9 \%)$, higher education of father and mother $(71.4 \%$ and $64.3 \%$ respectively), and children caregiver was mother (82.1\%). There were a significant diference $(p<0.05)$ in father profession, parents' education, household economic status, and caregiver of children, whereas anthropometric measurement did not show any difference between two groups. Determinants of malnutrition in urban and rural groups is the number of children in the family.

Key words: Children under five, demographic characteristic, severe acute malnutrition, rural, urban

\section{Pendahuluan}

Malnutrisi masih merupakan permasalahan di Indonesia termasuk di Daerah Istimewa Yogyakarta. Prevalensi status gizi balita berdasarkan berat badan per tinggi badan (BB/TB) di Daerah Istimewa Yogyakarta menunjukkan prevalensi status gizi balita sangat kurus 2,6\% dan kurus 6,5\%.1 Data dari Kementerian

Korespondensi: Titih Huriah, Dep. Kep. Komunitas Prodi Ilmu Keperawatan FKIK UMY, Kampus Terpadu UMY, Jl. Ringroad Selatan Tamantirto Kasihan Bantul Yogyakarta, Hp.081392405406,e-mail: titih_psikumy@yahoo.com 
Kesehatan tahun 2011 menunjukkan bahwa secara nasional prevalensi status gizi di provinsi Daerah Istimewa Yogyakarta berdasarkan berat badan per umur $(\mathrm{BB} / \mathrm{U})$, gizi buruk di DIY mencapai 1,4\%, berdasarkan tinggi badan per umur $(\mathrm{TB} / \mathrm{U})$, sangat pendek $10,2 \%$, berdasarkan tinggi badan per umur dan berat badan per tinggi badan, pendek-kurus $0,4 \%$, dan berdasarkan berat badan per tinggi badan $(\mathrm{BB} / \mathrm{TB})$, balita sangat kurus $2,6 \% .^{2}$

Akar permasalahan malnutrisi pada balita adalah ketidaktepatan asuhan, lingkungan yang tidak mendukung, dan makanan yang tidak tepat atau tidak sesuai dengan fase tumbuh kembang. ${ }^{3,4}$ Faktor lain yang juga mempengaruhi adalah rendahnya aksesibilitas pangan (kemampuan rumah tangga untuk selalu memenuhi kebutuhan pangan anggotanya) mengancam penurunan konsumsi makanan yang beragam, bergizi seimbang, dan aman di tingkat rumah tangga. 5,6

Beberapa penelitian yang dilakukan menyatakan determinan kejadian malnutrisi pada anak adalah usia anak, jenis kelamin anak, anak kembar, interval kelahiran, pendidikan ibu, status pernikahan, tingkat kesejahteraan rendah, perilaku pencarian kesehatan, dan jumlah anak. Beberapa penelitian menunjukkan variabel pendidikan ibu merupakan variabel yang paling berpengaruh terhadap kejadian malnutrisi pada balita. ${ }^{7,8,9}$ Penelitian yang dilakukan pada balita malnutrisi di Bangladesh dan Nepal menyatakan terdapat perbedaan karakteristik antara responden perkotaan dan pedesaan yaitu perbedaan dalam skor-z, jenis kelamin, vaksinasi pada anak, pendidikan orang tua, tingkat kesejahteraan, rasio ketergantungan dan jumlah anak yang berusia kurang dari lima tahun. ${ }^{10}$ Faktor-faktor lain selain faktor kesehatan, tetapi juga merupakan masalah utama gizi buruk adalah stigma masyarakat, sosial budaya, kemiskinan, pendidikan rendah, ketersediaan pangan dan kesempatan kerja sebagai dampak urbanisasi. ${ }^{11,12}$ Penelitian ini bertujuan untuk mengidentifikasi kejadian malnutrisi akut berat dan determinannya pada balita di wilayah perkotaan dan perdesaan di Yogyakarta.

\section{Metode}

Desain penelitian yang digunakan adalah desain survey dengan pendekatan potong lintang. Populasi pada penelitian ini adalah semua balita malnutrisi akut berat dengan dan atau tanpa komplikasi berusia 6 - 60 bulan di Kota Yogyakarta dan Kabupaten Sleman yang berjumlah 56 balita. Sampel adalah semua balita malnutrisi akut berat dengan kriteria usia 6 - 60 bulan di Kota Yogyakarta dan Kabupaten Sleman. Kriteria inklusi yang diterapkan yaitu populasi balita malnutrisi akut berat tanpa komplikasi (BB/PB atau BB/TB: <-3 SD Z-score) atau balita malnutrisi akut sedang dengan komplikasi (BB/PB atau BB/TB: <-2 SD skor-z) yang dirawat di rumah atau setelah perawatan di rumah sakit (fase rehabilitasi) namun masih menderita malnutrisi. Kriteria eksklusi pada penelitian ini adalah balita malnutrisi akut sedang (BB/PB atau BB/TB: <-2 SD Z-score) yang jatuh pada kondisi malnutrisi akut berat $(\mathrm{BB} / \mathrm{PB}$ atau $\mathrm{BB} / \mathrm{TB}$ : $<-3$ SD Z-score) yang harus dirawat di Rumah Sakit dengan kriteria terdapat bilateral pitting edema, dan terdapat satu gejala ISPA, demam tinggi, anemia berat, dan tidak sadar.

Analisis yang digunakan adalah WHO Anthro untuk menganalisis pengukuran antropometri untuk indikator BB/TB. Nilai rerata dan standar deviasi digunakan untuk menganalisis data kontinu, sedangkan rasio dan proporsi digunakan untuk menganalisis data kategori. Variabel kategori dilakukan komparasi dan korelasi dengan menggunakan uji Pearson Chi Square $\left(X^{2}\right)$, independent $t$-test digunakan untuk menganalisis perbedaan dari data kontinu antara wilayah urban dan rural, dan uji regresi logistik untuk mengetahui determinan kejadian malnutrisi akut. Statistik signifikan yang diterima apabila nilai $\mathrm{P}<$ 0,05 .

\section{Pengukuran Antropometri}

Alat yang digunakan untuk mengukur berat badan adalah timbangan berat badan digital yang telah dikalibrasi dengan kapasitas $150 \mathrm{~kg}$ dan ketelitian 50 gram; menggunakan baterai $3 \mathrm{~A}$ sebanyak dua buah. Pengukuran berat badan pada anak yang sudah bisa berdiri dengan cara responden diminta naik ke alat timbang dengan posisi kaki tepat di tengah alat timbang tetapi tidak menutupi jendela baca. Pengukuran berat badan pada anak yang umur kurang dari dua tahun atau anak yang belum bisa berdiri adalah dengan menimbang ibu terlebih dahulu, kemudian menimbang ibu dan anak (digendong) bersama-sama. Berat badan anak adalah selisih antara (berat badan ibu dan anak) dengan berat badan ibu. Timbangan digital telah dikalibrasi sebelum pelaksanaan penelitian.

Pengukuran tinggi badan pada responden $\geq 2$ tahun dilakukan dalam posisi berdiri dengan menggunakan microtoise dengan kapasitas ukur dua meter dan ketelitian $0,1 \mathrm{~cm}$. Responden diminta berdiri tegak, persis di bawah alat geser. Posisi kepala dan bahu bagian belakang, lengan, pantat, dan tumit menempel pada dinding tempat microtoise dipasang. Pengukuran tinggi badan pada responden kurang dari dua tahun atau belum bisa berdiri dilakukan dengan pengukur panjang badan diletakkan pada meja atau tempat yang rata, dan baringkan anak dengan posisi telentang diantara kedua siku, kepala anak menempel pada bagian panel yang tidak dapat digeser. Seorang anak yang berumur kurang dari dua tahun diukur tinginya dengan berdiri maka ditambahkan 0,7 $\mathrm{cm}$ untuk mengonversi menjadi panjang badan. Anak yang berusia dua tahun atau lebih dan diukur panjangnya 
dengan telentang maka dikurangi $0,7 \mathrm{~cm}$ untuk mengonversi menjadi tinggi badan.

Hasil pengukuran berat badan dan tinggi badan diolah dengan perangkat WHO Anthro untuk mengetahui nilai Z-score. Malnutrisi akut berat diukur dengan menggunakan indikator $\mathrm{BB} / \mathrm{TB}$ atau $\mathrm{BB} / \mathrm{PB}$ (wasted) dengan kategori $<70 \%$ nilai median $\mathrm{BB} / \mathrm{TB}$ atau z score $<-3 \mathrm{SD}$ dan malnutrisi akut dengan komplikasi $(<80 \%$ nilai median $\mathrm{BB} / \mathrm{TB}$ atau <-2 SD). 13,14

\section{Karakteristik Sosial Demografi dan Ekonomi}

Karakteristik yang diteliti meliputi usia anak, jenis kelamin anak, jumlah balita dalam keluarga, usia ibu, tingkat pendidikan tertinggi ibu dan ayah, pendapatan keluarga dalam 1 bulan, pemberian ASI eksklusif, dan pengasuh anak di rumah. Tingkat pendidikan ayah dan ibu diukur dengan melihat tingkat pendidikan tertinggi yang diselesaikan orang tua kemudian dikategorikan menjadi rendah (SMP sederajat dan dibawahnya) dan tinggi (SMA sederajat dan diatasnya). Pendapatan keluarga diukur dengan menghitung total pendapatan keluarga dalam satu bulan yang dibandingkan dengan UMR Kota Yogyakarta (Rp 1.065.247), kemudian dikategorikan menjadi pendapatan kurang dari UMR dan pendapatan lebih dari atau sama dengan UMR.

\section{Hasil}

Tabel 1 menyajikan data karakteristik sosial demografi dan ekonomi balita malnutrisi akut berat baik pada kelompok urban maupun rural. Pada variabel jumlah balita dalam keluarga, persentase antara kelompok urban dan rural hampir sama yaitu lebih dari 50\% keluarga hanya mempunyai satu balita dalam keluarga. Hal yang sama juga terjadi pada variabel jenis kelamin, di mana laki-laki mempunyai prevalensi lebih besar dari pada perempuan pada kedua kelompok. Pada variabel pemberian ASI eksklusif, lebih dari $60 \%$ balita tidak mendapatkan ASI eksklusif. Usia ibu baik pada kelompok urban maupun rural, lebih dari 60\% termasuk kategori usia subur yaitu kurang dari 35 tahun.

Tabel 1 juga memperlihatkan bahwa hampir 100\% pekerjaan orang tua adalah nonPNS. Variabel penghasilan keluarga menunjukkan pendapatan kelompok urban lebih baik daripada kelompok rural. Variabel tingkat pendidikan menunjukkan tingkat pendidikan ayah lebih baik daripada tingkat pendidikan ibu baik pada kelompok urban maupun rural. Variabel pengasuh balita menunjukkan lebih dari $80 \%$ balita di asuh langsung oleh ibunya. Hasil uji beda antara kelompok urban dan kelompok rural menunjukkan perbedaan pada variabel pekerjaan orang tua, penghasilan orang tua, tingkat pendidikan ibu, tingkat pendidikan ayah dan pengasuh balita di rumah dengan nilai $\mathrm{p}<0,05$.

Tabel 1 menyajikan data bahwa faktor risiko kejadian malnutrisi akut pada kelompok urban dan rural adalah jumlah balita dalam keluarga 1 orang $(60,7 \%)$, jenis kelamin laki-laki $(58,9 \%)$, riwayat pemberian ASI tidak eksklusif $(60,7 \%)$, usia ibu kurang dari 35 tahun $(62,5 \%)$, pekerjaan nonPNS $(98,2 \%)$, penghasilan orang tua lebih dari UMR $(58,9 \%)$, tingkat pendidikan ayah dan ibu tinggi $(71,4 \%$ dan $64,3 \%)$ dan pengasuh balita di rumah adalah ibu $(82,1 \%)$.

Tabel 2 menyajikan data perbedaan pengukuran antropometri responden penelitian. Rata-rata usia responden pada kelompok urban adalah 33,24 bulan dan 30,61 bulan pada kelompok rural. Variabel antropometri

Tabel 1. Distribusi Karakteristik Sosial Demografi dan Ekonomi Responden Penelitian Berdasarkan Tempat Tinggal (Urban dan Rural) (N=56)

\begin{tabular}{|c|c|c|c|c|c|c|c|c|}
\hline \multirow{2}{*}{ Karakteristik } & \multirow{2}{*}{ Kategori } & \multicolumn{2}{|c|}{ Total $(\mathrm{N}=56)$} & \multicolumn{2}{|c|}{ Urban $(n=33)$} & \multicolumn{2}{|c|}{ Rural (n=23) } & \multirow{2}{*}{ Nilai p } \\
\hline & & $\mathbf{n}$ & $\%$ & $\mathbf{n}$ & $\%$ & $\mathbf{n}$ & $\%$ & \\
\hline \multirow[t]{2}{*}{ Jumlah balita dalam keluarga } & 1 orang & 34 & 60,7 & 22 & 66,7 & 12 & 52,2 & 0,1000 \\
\hline & Lebih dari 1 orang & 22 & 39,3 & 11 & 33,3 & 11 & 47,8 & \\
\hline \multirow{2}{*}{ Jenis kelamin } & Laki-laki & 33 & 58,9 & 20 & 60,6 & 13 & 56,5 & 0,7600 \\
\hline & Perempuan & 23 & 41,1 & 13 & 39,4 & 10 & 43,5 & \\
\hline \multirow{2}{*}{ Riwayat pemberian ASI eksklusif } & Eksklusif & 22 & 39,3 & 14 & 42,4 & 8 & 34,8 & 0,1400 \\
\hline & Tidak eksklusif & 34 & 60,7 & 19 & 57,6 & 15 & 65,2 & \\
\hline \multirow[t]{2}{*}{ Usia ibu saat validasi } & $<35$ tahun & 35 & 62,5 & 20 & 60,6 & 15 & 65,2 & 0,0600 \\
\hline & $\geq 35$ tahun & 21 & 37,5 & 13 & 39,4 & 8 & 34,8 & \\
\hline \multirow[t]{2}{*}{ Pekerjaan orang tua } & PNS & 1 & 1,8 & 1 & 3,0 & 0 & 0 & 0,0001 \\
\hline & Non PNS & 55 & 98,2 & 32 & 97,0 & 23 & 100,0 & \\
\hline \multirow[t]{2}{*}{ Penghasilan orang tua } & $\geq \mathrm{UMR}$ & 33 & 58,9 & 17 & 51,5 & 6 & 26,1 & 0,0200 \\
\hline & $<$ UMR & 23 & 41,1 & 16 & 48,5 & 17 & 73,9 & \\
\hline \multirow[t]{2}{*}{ Tingkat pendidikan ibu } & Tinggi & 36 & 64,3 & 24 & 72,7 & 12 & 65,2 & 0,0300 \\
\hline & Rendah & 20 & 35,7 & 9 & 27,3 & 11 & 34,8 & \\
\hline \multirow[t]{2}{*}{ Tingkat pendidikan ayah } & Tinggi & 40 & 71,4 & 25 & 75,8 & 15 & 65,2 & 0,0010 \\
\hline & Rendah & 16 & 28,6 & 8 & 24,2 & 8 & 34,8 & \\
\hline \multirow[t]{2}{*}{ Pengasuh balita di rumah } & Ibu & 46 & 82,1 & 26 & 78,8 & 20 & 87,0 & $0,0001^{*}$ \\
\hline & Bukan ibu & 10 & 17,9 & 7 & 21,2 & 3 & 13,0 & \\
\hline
\end{tabular}

nilai p dari nilai $\mathrm{X}^{2}$ perbedaan 2 kelompok; *Analisis menggunakan Fisher Exact Test 
Huriah, Trisnantoro, Haryanti, Julia, Malnutrisi Akut-Berat dan Determinannya pada Balita di Wilayah Rural dan Urban

Tabel 2. Distribusi Pengukuran Antropometri Responden Penelitian Berdasarkan Tempat Tinggal (Urban dan Rural) (N=56)

\begin{tabular}{|c|c|c|c|c|}
\hline \multirow{2}{*}{ Variabel } & Kelompok Urban (n=33) & Kelompok Rural (n=23) & \multirow{2}{*}{ Mean Diff (95\% CI) } & \multirow{2}{*}{ Nilai $p$} \\
\hline & Rerata \pm SD & Rerata \pm SD & & \\
\hline Usia (bulan) & $33,24 \pm 12,41$ & $30,61 \pm 16,23$ & $(-5,04,10,31)$ & 0,49 \\
\hline Berat badan $(\mathrm{kg})$ & $8,97 \pm 1,60$ & $8,27 \pm 1,89$ & $(-0,25,1,64)$ & 0,14 \\
\hline Tinggi badan $(\mathrm{TB}) /$ panjang badan $(\mathrm{PB})$ & $84,68 \pm 8,77$ & $81,13 \pm 10,37$ & $(-1,60,8,69)$ & 0,17 \\
\hline $\mathrm{Z}$ score $\mathrm{BB} / \mathrm{TB}$ & $-3,13 \pm-0,34$ & $-3,24 \pm 0,23$ & $(-0,06,0,27)$ & 0,44 \\
\hline
\end{tabular}

nilai $\mathrm{p}$ dari analisis independent t-test perbedaan 2 kelompok

Tabel 3. Karakteristik Sosial Ekonomi dan Demografi Berdasarkan Distribusinya terhadap Nilai Z-score BB/TB (Urban dan Rural) (N=56)

\begin{tabular}{|c|c|c|c|c|c|}
\hline \multirow{3}{*}{ Karakteristik } & \multirow{3}{*}{ Kategori } & \multicolumn{2}{|c|}{ Z-score BB/TB } & \multicolumn{2}{|c|}{ Z-score BB/TB } \\
\hline & & \multicolumn{2}{|c|}{ Urban $(n=33)$} & \multicolumn{2}{|c|}{ Rural (n=23) } \\
\hline & & Rerata \pm SD & 95\% CI & Rerata \pm SD & $95 \% \mathrm{CI}$ \\
\hline \multirow[t]{2}{*}{ Jumlah balita dalam keluarga } & 1 orang & $-3,15 \pm 0,34$ & $(-3,29,-2,99)$ & $-3,28 \pm 0,22$ & $(-3,43,-3,12)$ \\
\hline & Lebih dari 1 orang & $-3,10 \pm 0,35$ & $(-3,33,-2,87)$ & $-3,19 \pm 0,24$ & $(-3,34,-3,05)$ \\
\hline \multirow[t]{2}{*}{ Jenis kelamin } & Laki-laki & $-3,16 \pm 0,39$ & $(-3,34,-2,98)$ & $-3,19 \pm 0,20$ & $(-3,31,-3,07)$ \\
\hline & Perempuan & $-3,08 \pm 0,26$ & $(-3,24,-2,93)$ & $-3,29 \pm 0,26$ & $(-3,48,-3,11)$ \\
\hline \multirow[t]{2}{*}{ Riwayat pemberian ASI eksklusif } & Eksklusif & $-3,18 \pm 0,39$ & $(-3,41,-2,96)$ & $-3,34 \pm 0,27$ & $(-3,55,-3,10)$ \\
\hline & Tidak eksklusif & $-3,09 \pm 0,30$ & $(-3,24,-2,95)$ & $-3,19 \pm 0,19$ & $(-3,29,-3,08)$ \\
\hline \multirow[t]{2}{*}{ Usia ibu } & $<35$ tahun & $-3,11 \pm 0,37$ & $(-3,28,-2,94)$ & $-3,22 \pm 0,24$ & $(-3,36,-3,09)$ \\
\hline & $\geq 35$ tahun & $-3,17 \pm 0,30$ & $(-3,35,-2,98)$ & $-3,26 \pm 0,21$ & $(-3,43,-3,09)$ \\
\hline \multirow[t]{2}{*}{ Pekerjaan orang tua } & PNS & $-3,00$ & & & \\
\hline & Non PNS & $-3,13 \pm 0,34$ & $(-3,26,-3,01)$ & $-3,24 \pm 0,23$ & $(-3,33,-3,14)$ \\
\hline \multirow[t]{2}{*}{ Penghasilan orang tua } & $\geq \mathrm{UMR}$ & $-3,16 \pm 0,29$ & $(-3,32,-3,02)$ & $-3,35 \pm 0,29$ & $(-3,66,-3,05)$ \\
\hline & $<$ UMR & $-3,09 \pm 0,39$ & $(-3,29,-2,88)$ & $-3,19 \pm 0,19$ & $(-3,29,-3,09)$ \\
\hline \multirow[t]{2}{*}{ Tingkat pendidikan Ibu } & Tinggi & $-3,15 \pm 0,35$ & $(-3,30,-3,01)$ & $-3,30 \pm 0,26$ & $(-3,47,-3,14)$ \\
\hline & Rendah & $-3,07 \pm 0,32$ & $(-3,31,-2,83)$ & $-3,16 \pm 0,16$ & $(-3,27,-3,06)$ \\
\hline \multirow{2}{*}{ Tingkat pendidikan ayah } & Tinggi & $-3,14 \pm 0,34$ & $(-3,29,-3,00)$ & $-3,26 \pm 0,25$ & $(-3,39,-3,12)$ \\
\hline & Rendah & $-3,09 \pm 0,34$ & $(-3,38,-2,80)$ & $-3,19 \pm 0,17$ & $(-3,39,-3,12)$ \\
\hline \multirow[t]{2}{*}{ Pengasuh balita di rumah } & Ibu & $-3,10 \pm 0,35$ & $(-3,24,-2,96)$ & $-3,22 \pm 0,22$ & $(-3,33,-3,12)$ \\
\hline & Bukan ibu & $-3,24 \pm 0,29$ & $(-3,51,-2,97)$ & $-3,33 \pm 0,27$ & $(-3,99,-2,67)$ \\
\hline
\end{tabular}

Tabel 4. Prevalensi Status Gizi Balita Malnutrisi Akut (Urban dan Rural) (N=56)

\begin{tabular}{|c|c|c|c|c|}
\hline \multirow{2}{*}{ Status Gizi } & \multicolumn{2}{|c|}{ Urban $(n=33)$} & \multicolumn{2}{|c|}{ Rural (n=23) } \\
\hline & Frekuensi $(\%)$ & Nilai p* & Frekuensi (\%) & Nilai p \\
\hline Malanutrisi akut berat & $26(78,8)$ & 0,001 & $16(69,6)$ & 0,06 \\
\hline Malanutrisi akut sedang dengan komplikasi & $7(21,2)$ & & $7(30,4)$ & \\
\hline
\end{tabular}

yang lainnya terlihat hampir sama antara kelompok urban dan rural, hal ini dibuktikan dengan hasil analisis menunjukkan tidak terdapat perbedaan hasil pengukuran antropometri antara kedua kelompok dengan nilai $\mathrm{p}>$ 0.05 .

Tabel 3 menyajikan data distribusi karakteristik sosial ekonomi dan demografi berdasarkan $\mathrm{Z}$ score $\mathrm{BB} / \mathrm{TB}$. Tabel 3 memperlihatkan kategori variabel yang terdistribusi pada rerata $\mathrm{Z}$ score paling rendah pada kelompok urban adalah jumah balita dalam keluarga 1 orang, jenis kelamin laki-laki, riwayat pemberian ASI eksklusif, usia $i b u \geq 35$ tahun, pekerjaan orang tua nonPNS, penghasilan orang tua $\geq$ UMR, tingkat pendidikan ayah dan ibu tinggi, serta pengasuh balita di rumah bukan ibu. Hal yang sama terjadi pada kelompok rural, kecuali pada kelompok rural jenis kelamin perempuan mempunyai rerata $\mathrm{Z}$ score paling rendah daripada kelompok laki-laki.

Hasil analisis pada Tabel 4 menunjukkan prevalensi malnutrisi akut berat mempunyai persentase lebih besar baik pada balita di wilayah urban maupun rural. Hasil uji beda menunjukkan terdapat perbedaan status gizi pada kelompok urban, namun tidak ada perbedaan pada kelompok rural.

Analisis dilanjutkan dengan analisis bivariabel dan multivariabel untuk mengetahui determinan kejadian malnutrisi pada balita di wilayah urban dan rural. Pada analisis korelasi, status gizi balita malnutrisi akut dibagi menjadi dua kategori yaitu balita malnutrisi akut berat (BB/PB atau BB/TB: <-3 SD Z-score) dan malnutrisi akut 
Tabel 5. Hubungan Karakteristik Demografi terhadap Status Gizi Balita Malnutrisi Akut pada Wilayah Urban dan Rura

\begin{tabular}{|c|c|c|c|c|c|c|c|}
\hline \multirow{2}{*}{ Variabel } & \multirow{2}{*}{ Kategori } & \multicolumn{3}{|c|}{ Urban $(n=33)$} & \multicolumn{3}{|c|}{ Rural (n=23) } \\
\hline & & MAB (\%) & MAS (\%) & Nilai $p$ & MAB (\%) & MAS (\%) & Nilai $p$ \\
\hline \multirow[t]{2}{*}{ Jumlah balita dalam keluarga } & 1 orang & $16(72,7)$ & $6(27,3)$ & 0,23 & $7(58,3)$ & $5(41,7)$ & 0,22 \\
\hline & Lebih dari 1 orang & $10(90,9)$ & $1(9,1)$ & & $9(81,8)$ & $2(18,2)$ & \\
\hline \multirow{2}{*}{ Jenis Kelamin } & Laki-laki & $16(80,0)$ & $4(20,0)$ & 0,58 & $8(61,5)$ & $5(38,5)$ & 0,31 \\
\hline & Perempuan & $10(76,9)$ & $3(23,1)$ & & $8(80,0)$ & $2(20,0)$ & \\
\hline \multirow[t]{2}{*}{ Riwayat pemberian ASI eksklusif } & Eksklusif & $11(78,6)$ & $3(21,4)$ & 0,65 & $7(87,5)$ & $1(12,5)$ & 0,19 \\
\hline & Tidak eksklusif & $15(78,9)$ & $4(21,1)$ & & $9(60,0)$ & $6(40,0)$ & \\
\hline \multirow[t]{2}{*}{ Usia ibu saat validasi } & $<35$ tahun & $15(75,0)$ & $5(25,0)$ & 0,41 & $11(73,3)$ & $4(26,7)$ & 0,47 \\
\hline & $\geq 35$ tahun & $11(84,6)$ & $2(15,4)$ & & $5(62,5)$ & $3(37,5)$ & \\
\hline \multirow[t]{2}{*}{ Pekerjaan orang tua } & PNS & $1(100,0)$ & $0(0)$ & 0,79 & 0 & 0 & - \\
\hline & Non PNS & $25(78,1)$ & $7(21,9)$ & & $16(69,6)$ & $(30,4)$ & \\
\hline \multirow{2}{*}{ Penghasilan orang tua } & $\geq \mathrm{UMR}$ & $14(82,4)$ & $3(17,6)$ & 0,46 & $6(100,0)$ & $0(0)$ & 0,08 \\
\hline & $<$ UMR & $12(75,0)$ & $4(25,0)$ & & $10(58,8)$ & $7(41,2)$ & \\
\hline \multirow{2}{*}{ Tingkat pendidikan Ibu } & Tinggi & $18(75,0)$ & $6(25,0)$ & 0,36 & $8(66,7)$ & $4(33,3)$ & 0,56 \\
\hline & Rendah & $8(88,9)$ & $1(11,1)$ & & $8(72,7)$ & $3(27,3)$ & \\
\hline \multirow[t]{2}{*}{ Tingkat pendidikan ayah } & Tinggi & $19(76,0)$ & $6(24,0)$ & 0,44 & $10(66,7)$ & $5(33,3)$ & 0,53 \\
\hline & Rendah & $7(87,5)$ & $1(12,5)$ & & $6(75,0)$ & $2(25,0)$ & \\
\hline \multirow[t]{2}{*}{ Pengasuh balita di rumah } & Ibu & $20(76,9)$ & $6(23,1)$ & 0,53 & $14(70,0)$ & $6(30,0)$ & 0,68 \\
\hline & Bukan Ibu & $6(85,7)$ & $1(14,3)$ & & $2(66,7)$ & $1(33,3)$ & \\
\hline
\end{tabular}

Keterangan : MAB (Malnutrisi akut berat, Skor-z BB/TB : $\geq-3$ SD),

MAS (Malnutrisi akut sedang dengan komplikasi, Skor-z BB/TB : <- 3SD)

" $\alpha<0,05$ based on Fisher Exact Test

Tabel 6. Model Regresi Logistik Variabel yang Berhubungan dengan Status Gizi Balita Malanutrisi pada Kelompok Rural (n=23)

\begin{tabular}{llll}
\hline Determinan & B & OR & Nilai p \\
\hline Jumlah balita dalam keluarga & 1,67 & 5,32 & 0,13 \\
Riwayat pemberian ASI eksklusif & $-0,54$ & 0,58 & 0,69 \\
Penghasilan orang tua & $-21,10$ & 0,00 & 0,99 \\
\hline
\end{tabular}

-2 Log likelihood = 19,96; Nagelkerke R Square = 0,43

sedang dengan komplikasi $(\mathrm{BB} / \mathrm{PB}$ atau $\mathrm{BB} / \mathrm{TB}:<-2 \mathrm{SD}$ $Z$-score). Analisis multivariabel dengan regresi logistik dilakukan pada variabel yang mempunyai korelasi dengan nilai $\mathrm{p}<0,25$.

Hasil analisis pada Tabel 5 menunjukkan pada balita malnutrisi akut di wilayah urban, tidak terdapat karakteristik demografi yang berhubungan dengan status gizi balita malnutrisi. Variabel yang mempunyai nilai $\mathrm{p}<0,25$ hanya satu variabel yaitu jumlah balita dalam keluarga, sehingga untuk wilayah urban tidak dapat dilanjutkan ke analisis multivariabel. Pada wilayah rural, walaupun tidak terdapat karakteristik demografi yang berhubungan dengan status gizi balita malnutrisi akut, namun terdapat tiga variabel yang mempunyai nilai $p<0,25$ yaitu jumlah balita dalam keluarga, riwayat pemberian ASI dan penghasilan orang tua sehingga untuk balita di wilayah rural dilanjutkan ke analisis multivariabel.

Hasil analisis pada Tabel 6 menunjukkan jumlah balita dalam keluarga merupakan variabel yang paling mempengaruhi status gizi balita malnutrisi dengan nilai $\mathrm{p}=$ 0,13. Nilai Nagelkerke R Square menunjukkan ketiga variabel bebas dari status gizi balita yang bisa dijelaskan oleh model adalah sebesar $43 \%$ dan sisanya yaitu 58\% dijelaskan faktor lain.

\section{Pembahasan}

Sampel pada penelitian ini adalah semua balita malnutrisi di dua kabupaten kota di Provinsi Yogyakarta. Jumlah balita malnutrisi di Kota Yogyakarta (urban) mencapai 58,93\% dari seluruh responden penelitian. Kota Yogyakarta merupakan wilayah perkotaan (urban), hal ini sesuai dengan pernyataan bahwa kejadian malnutrisi pada balita lebih banyak terjadi di wilayah urban. Data survei antropometri di beberapa negara di Afrika dan Asia menunjukkan kejadian malnutrisi akut (wasted) lebih sering terjadi di wilayah perkotaan. ${ }^{7,15,16}$ Wilayah urban memiliki karakteristik padat penduduk, ventilasi yang tidak adekuat, kurangnya ketersediaan air bersih, tingginya angka kriminal, dan tingginya angka penyebaran penyakit. ${ }^{15}$ Karakteristik ini sangat memengaruhi status gizi balita dimana Kota Yogyakarta saat ini merupakan wilayah yang paling tinggi angka kejadian malnutrisi pada balita.

Faktor risiko kejadian malnutrisi pada kelompok urban dan rural adalah usia balita 30 - 33 bulan, jumlah balita dalam keluarga 1 orang $(60,7 \%)$, jenis kelamin laki-laki $(58,9 \%)$, riwayat pemberian ASI tidak eksklusif $(60,7 \%)$, usia ibu kurang dari 35 tahun $(62,5 \%)$, pekerjaan nonPNS $(98,2 \%)$, penghasilan orang tua lebih dari UMR $(58,9 \%)$, tingkat pendidikan ayah dan ibu tinggi (71,4\% dan $64,3 \%)$ dan pengasuh balita di rumah adalah ibu $(82,1 \%)$.

Karakteristik balita malnutrisi berdasarkan usia menunjukkan rerata usia balita adalah usia 30 - 33 bulan. 
Kejadian kekurangan gizi juga biasanya terjadi pada 1000 hari pertama kehidupan karena merupakan usia yang paling berisiko dalam gangguan pertumbuhan dan kejadian malnutrisi. ${ }^{17,18}$ Pada usia dua tahun pertama, sering terjadi gangguan pertumbuhan karena periode ini merupakan periode kritis kehidupan. ${ }^{19}$ Kejadian malnutrisi pada usia ini juga terjadi karena tidak adekuatnya kualitas makanan tambahan setelah pemberian ASI dan peningkatan kejadian infeksi. Hal ini sesuai dengan karakteristik balita malnutrisi dimana $60,7 \%$ balita malnutrisi tidak mendapatkan ASI eksklusif.

Masalah kekurangan gizi pada anak balita ini merupakan dampak dari rendahnya pemberian ASI eksklusif sampai enam bulan dan pemberian makanan pendamping ASI yang tidak tepat karena diberikan terlalu dini atau terlambat, jumlahnya tidak cukup untuk memenuhi kebutuhan pertumbuhan dan perkembangan bayi pada setiap tahapan usia dan tidak bergizi seimbang untuk memenuhi asupan kalori, protein dan gizi mikro (vitamin dan mineral). Data menunjukkan keluarga yang mempunyai perilaku pemberian makanan bayi yang benar hanya $41 \% .{ }^{20}$ Ketersediaan pangan lokal beragam telah dapat diakses oleh sebagian keluarga karena dari $41 \%$ keluarga yang memberikan makanan pendamping ASI yang benar tersebut ternyata MP-ASI yang diberikan berasal dari sumber pangan lokal yang memenuhi $70 \%$ kebutuhan besi dan $87 \%$ kebutuhan vitamin A. ${ }^{20}$ Beberapa penelitian menyatakan bahwa sebagian besar balita malnutrisi tidak mendapatkan ASI eksklusif.10,21 Angka cakupan ASI eksklusif terus mengalami penurunan dan pemberian susu formula pada bayi semakin meningkat meskipun para tenaga kesehatan telah bekerja sama untuk meningkatkan pemberian ASI eksklusif. ${ }^{22} \mathrm{Hal}$ ini yang merupakan salah satu faktor pemicu kejadian malnutrisi pada balita.

Jenis kelamin balita malnutrisi sebagian besar laki-laki. Hal ini sesuai dengan beberapa penelitian yang menunjukkan bahwa anak laki-laki lebih cenderung mengalami malnutrisi daripada anak perempuan. ${ }^{7,8,9}$ Apabila dikaitkan dengan usia, karakteristik perkembangan usia toddler adalah tidak bisa diam, aktif dan penuh rasa ingin tahu. Permainan anak laki-laki lebih aktif daripada anak perempuan dan membutuhkan energi yang lebih banyak. Apabila aktivitas ini tidak diimbangi dengan nutrisi yang cukup maka akan menjadi faktor risiko kejadian malnutrisi.

Beberapa penelitian yang dilakukan menyatakan determinan kejadian malnutrisi pada anak adalah usia anak, jenis kelamin anak, anak kembar, interval kelahiran, pendidikan ibu, status pernikahan, tingkat kesejahteraan rendah, perilaku pencarian kesehatan, dan jumlah anak. Variabel pendidikan ibu merupakan variabel yang paling berpengaruh terhadap kejadian malnutrisi pada balita. ${ }^{7,8,9}$ Faktor-faktor lain selain faktor ke- sehatan, tetapi juga merupakan masalah utama gizi buruk adalah stigma masyarakat, sosial budaya, kemiskinan, pendidikan rendah, ketersediaan pangan dan kesempatan kerja sebagai dampak urbanisasi. ${ }^{11,12} \mathrm{Hal}$ ini sesuai dengan salah satu karakteristik bahwa pekerjaan orang tua balita malnutrisi sebagian besar adalah non PNS.

Variabel yang lainnya merupakan variabel yang positif seperti usia ibu kurang dari 35 tahun, penghasilan orang tua lebih dari UMR, tingkat pendidikan ayah dan ibu tinggi dan pengasuh balita di rumah adalah ibu. Kejadian malnutrisi lebih dipengaruhi faktor lain seperti penyakit infeksi, konsumsi makanan, pelayanan kesehatan, dan pola asuh. Malnutrisi dapat disebabkan dari makanan yang tidak adekuat atau dapat disebabkan penyakit atau kecacatan. ${ }^{23}$ Faktor makanan dan penyakit infeksi saling mendorong dan berpengaruh satu sama lainnya.

Hasil analisis menunjukkan $82,1 \%$ balita diasuh oleh ibunya. Ibu sebagai pemberi asuhan utama merupakan kunci dalam peningkatan kesehatan anak usia kurang dari 3 tahun. Keterlibatan orang tua terutama ibu dalam memberikan asuhan nutrisi pada balita merupakan hal yang sangat penting dalam perubahan perilaku anak dan merupakan cara yang efektif untuk menurunkan kejadian malnutrisi pada bayi dan balita.

Hasil analisis menunjukkan tingkat pendidikan orang tua balita malnutrisi lebih dari $60 \%$ merupakan tingkat pendidikan tinggi. Hal ini tidak sesuai dengan pernyataan bahwa faktor pendidikan orang tua berperan penting dalam menstimulasi tumbuh kembang anak dan status gizi anak, terutama tingkat pendidikan yang dimiliki oleh seorang ibu yang akan berpengaruh secara langsung dalam pengasuhan anak. Apabila seorang ibu memiliki pengetahuan lebih tinggi, ibu akan mampu merawat anak dengan baik, mampu memilih nutrisi yang seimbang dan lebih berperan aktif dalam mencari infomasi terkait pengembangan keterampilan untuk merawat anak. ${ }^{24} \mathrm{Hal}$ ini kemungkinan dipengaruhi oleh faktor lain karena keadaan gizi anak pada tingkat rumah tangga dipengaruhi oleh kemampuan rumah tangga menyediakan pangan dalam jumlah dan jenis yang cukup serta pola asuh dalam rumah tangga. 25

Hasil analisis uji beda antara dua kelompok menunjukkan variabel yang berbeda antara kelompok urban dan rural yaitu variabel pekerjaan orang tua, penghasilan orang tua, tingkat pendidikan ayah, tingkat pendidikan ibu dan pengasuh balita di rumah. Variabel pekerjaan orang tua, penghasilan orang tua, tingkat pendidikan orangtua lebih baik pada kelompok urban daripada kelompok rural sedangkan untuk variabel pengasuh balita di rumah, kelompok rural lebih baik karena sebagian besar balita diasuh oleh ibunya.

Pada umumnya, mata pencaharian di daerah perde- 
saan adalah bertani tapi tak sedikit juga yang bermata pencaharian berdagang, sebab beberapa daerah pertanian tidak lepas dari kegiatan usaha. Mata pencaharian di daerah perkotaan lebih bervariasi dan lebih mengarah ke bidang industri.Variasi pekerjaan di daerah urban memungkinkan lapangan pekerjaan lebih terbuka luas di daerah perkotaan sehingga penghasilan mereka pun lebih variatif. Pendidikan orang tua yang lebih tinggi di wilayah urban memberikan kesempatan pada orang tua untuk mendapatkan pekerjaan yang lebih baik sehingga mereka mendapat penghasilan yang lebih tinggi. Di wilayah urban, lapangan pekerjaan terbuka baik untuk laki-laki dan perempuan sehingga sebagian besar perempuan merupakan wanita pekerja. Hal ini yang menyebabkan para ibu di daerah urban tidak mengasuh sendiri balitanya.

Hasil penelitian menunjukkan jumlah balita dalam keluarga merupakan faktor determinan kejadian malnutrisi akut pada balita di wilayah urban dan rural. Jumlah anggota keluarga akan memengaruhi konsumsi pangan. Pangan yang tersedia pada sebuah keluarga yang besar kemungkinan hanya cukup untuk keluarga yang besarnya setengah dari keluarga tersebut. Karena semakin banyaknya anggota keluarga, alokasi distribusi makanan dalam keluarga juga akan semakin sedikit. Jumlah anggota keluarga yang semakin besar tanpa diimbangi dengan meningkatnya pendapatan akan menyebabkan pendistribusian konsumsi pangan akan semakin tidak merata. 26

Kebutuhan nutrisi pada balita baik dari kualitas maupun kuantitas seharusnya lebih banyak daripada anggota keluarga lain. Apabila dalam satu keluarga terdapat lebih dari satu orang balita, keluarga harus menyediakan asupan nutrisi yang lebih besar. Pangan yang tersedia untuk suatu keluarga besar mungkin hanya cukup untuk mencegah timbulnya gangguan gizi pada keluarga besar. Jumlah anak yang menderita kelaparan pada keluarga besar, empat kali lebih besar dibandingkan dengan keluarga kecil. Anak dalam keluarga kecil memiliki pola dan tingkat konsumsi makanan yang lebih baik jika dibandingkan dengan anak dalam keluarga besar. Penelitian yang dilakukan oleh Srinivasan, Zanello dan Shankar ${ }^{10}$ pada 5267 balita malnutrisi di Bangladesh dan Nepal menyatakan terdapat perbedaan karakteristik sosial ekonomi, antara responden perkotaan dan pedesaan yaitu rasio ketergantungan dan jumlah anak yang berusia kurang dari 5 tahun.

\section{Kesimpulan}

Faktor risiko kejadian malnutrisi pada kelompok urban dan rural adalah usia balita 30-33 bulan, jumlah balita dalam keluarga 1 orang $(60,7 \%)$, jenis kelamin laki-laki $(58,9 \%)$, riwayat pemberian ASI tidak eksklusif $(60,7 \%)$, usia ibu kurang dari 35 tahun $(62,5 \%)$, peker- jaan nonPNS $(98,2 \%)$, penghasilan orang tua lebih dari UMR $(58,9 \%)$, tingkat pendidikan ayah dan ibu tinggi (71,4\% dan $64,3 \%)$ dan pengasuh balita di rumah adalah ibu $(82,1 \%)$. Hasil analisis uji beda antara dua kelompok menunjukkan variabel yang berbeda antara kelompok urban dan rural adalah variabel pekerjaan orang tua, penghasilan orang tua, tingkat pendidikan ayah, tingkat pendidikan ibu dan pengasuh balita di rumah. Variabel pekerjaan orang tua, penghasilan orang tua, tingkat pendidikan orangtua lebih baik pada kelompok urban daripada kelompok rural sedangkan untuk variabel pengasuh balita di rumah, kelompok rural lebih baik dimana sebagian besar balita diasuh oleh ibunya. Determinan kejadian malnutrisi akut di wilaah urban dan rural adalah jumlah balita dalam keluarga.

\section{Saran}

Hasil penelitian berguna untuk menentukan permasalahan dan mengidentifikasi determinan utama pada masing-masing kelompok sehingga dapat disusun strategi yang komprehensif untuk penanganan balita malnutrisi dengan mempertimbangkan determinan sosial demografi pada masing-masing area baik di perkotaan maupun perdesaan.

\section{Daftar Pustaka}

1. Kementerian Kesehatan Republik Indonesia. Profil kesehatan Indonesia Tahun 2011. Jakarta : Kementerian Kesehatan Indonesia; 2012.

2. Kementerian Kesehatan Republik Indonesia. Profil kesehatan Indonesia Tahun 2010. Jakarta: Kementerian Kesehatan Indonesia; 2011.

3. Huriah T. Hubungan perilaku ibu dalam memenuhi kebutuhan gizi terhadap status gizi balita di Kecamatan Beji Depok [tesis]. Depok: Universitas Indonesia; 2006.

4. Correa B, Merhi VAL, Fogaca KP, Oliveira MRM. Caregiver's education level, not income as determining factor of dietary intake and nutritional status of individuals cared for at home. The Journal of Nutrition Health and Aging. 2009; 13 (7): 609-14.

5. Goudet SM, Faiz S, Bogin BA, Griffihs PL. Pregnant women's and community health workers' perceptions of root causes of malnutrition among infants and young children in the slums of Dhaka. Bangladesh. American Journal of Public Health. 2011; 101 (7): 1225-33.

6. Svedberg. Peter. How many people are malnourished? Annual Review of Nutrition. 2011; 31: 263-83.

7. Fotso JC, Madise N, Baschieri A, Cleland J, Zulu E, Mutua MK, Essendi H. Child growth in urban deprived settings : does household poverty status matter? At which stage of child development? Health \& Place. 2012; 18: 375-84

8. Magadi Monica. Cross-national analysis of the risk factors of child malnutrition among children made vulnerable by HIV/AIDS in sub-Saharan Africa: evidence from the DHS. Tropical Medicine and International health. 2011; 16 (5): 570-8.

9. Abuya BA, James G, Kimani ME. Effect of mother's education on child's nutritional status in the slums of Nairobi. BMC Pediatrics. 2012; 12 : 80.

10. Srinivasan C, Zanello G, Shankar B. Rural-urban disparities in child nu- 
trition in Bangladesh and Nepal. BMC Public Health. 2013; 13: 581.

11. Kingori P, Muchimba M, Sikateyo B, Amadi B, Kelly P. Rumours and clinical trials: a retrospective examination of a pediatric malnutrition study in Zambia. Southern Africa. BMC Public Health. 2010; 10: 55.

12. Firestone R, Punpuing S, Peterson KE, Garcia DA, Gortmaker SL. Child overweight and undernutrition in Thailand: is there an urban effect? Social Science and Medicine. 2011; 72: 1420-8.

13. Collins S, Yates R. The need to update the classification of acute malnutrition. The Lancet. 2003; 362 (9379): 249.

14. World Health Organization. Child growth standards and the identification of severe acute malnutrition in infants and children. Geneva: WHO; 2009.

15. Nabag FO. Comparative study of nutritional status of urban and rural school girl's children Khartoum State Sudan. Jurnal of Science and Technology. 2011; 12 (02).

16. FAO [homepage in internet]. Assessment of nutritional status in urban areas. 2010 [cited 2014 Nov 5]. Available from: http://www.fao.org/ag/agn/nutrition/urban_assessment_en.stm.

17. Edeh Onyinya A. Addessing child malnutrition in Kopanga: lessons in transitioning from a homegrown nutrition program to a community-based program [thesis]. Washington: University of Washington; 2013.

18. Bhagowalia P. Chen Susan E. Masters WA. Effects and determinants of mild underweight among preschool children across countries and over time. Economics and Human Biology. 2011; 9: 66-77.

19. Roche. Marion Leslie. A community-based positive deviance/hearth inter- vention to improve infant and young child nutrition in the Ecuadorian Andes [thesis]. Montreal Quebec, Canada: McGill University; 2011.

20. BAPPENAS/Kementerian Perencanaan Pembangunan Nasional. Rencana aksi nasional pangan dan gizi 2011-2015. Jakarta: Bappenas; 2011.

21. Yang W, Li X, Zhang S, Liu L, Wang X, Li W. Anemia malnutrition and their correlation with socio-demographic characteristics and feeding practices among infants aged 0-18 months in rural areas of Shaanxi province in northwestern China: a cross-sectional study. BMC Public Health. 2012; 12: 1127.

22. Thompson ME, Keeling AA. Nurse's role in the prevention of infant mortality in 1884-1925: health disparities then and now. Journal of Pediatric Nursing. 2012; 27: 471-8.

23. Royal College of Nursing. Malnutrition: what nurses working with children and young people need to know and do. London Royal College of Nursing. 20 Cavendish Square; 2006.

24. Khomsan A. Pangan dan gizi untuk kesehatan. Jakarta: PT Grafindo Persada; 2010.

25. Soekirman. Ilmu gizi dan aplikasinya untuk keluarga dan masyarakat. Yogyakarta: Direktorat Jenderal Pendidikan Tinggi Departemen Pendidikan Nasional; 2005.

26. Dewanti M. Analisis pengaruh pendapatan keluarga, jumlah anggota keluarga, tingkat pendidikan ibu dan tingkat pendidikan ayah terhadap status gizi balita di Kecamatan Polokarto Kabupaten Sukoharjo [skripsi]. Solo: Universitas Negeri Sebelas Maret; 2008. 